\title{
Indian Universities and their Involvement in Patenting Activity
}

Lourden Selvamani and P. G. Arul

Department of International Business, Pondicherry University, Kalapet, Puducherry-605014, India; manilourden659@gmail.com, India pgarulibm@gmail.com

\begin{abstract}
Objective: The purpose of the study is to step forward in understanding the nexus between a university and patenting activity in Indian country context, thus paper process in identifying the patents granted to Indian universities by unearthing the top patentees and area on which the patent had been granted. Method: Patent grant data was captured from INPASS: Indian patent Advanced search system that launched in 2015 by the office of Controller General of Patents, Designs \& Trademark. The retrieved data entail period from 1958-2017, totally 59 years for 892 Indian universities comprising 48 central universities, 394 state universities, 325 private university and 125 deemed to be university. Results: Exploration revealed status of Indian Universities patent grants, our results show patenting activity is at a nascent stage since only 393 patents had been granted to 65 universities and a majority of patents are granted to the chemical technologies. Applications: Given the Government of India's resolution in strengthening Patent regime, the study shall aid policy makers to tailor better guidelines to stimulate Intellectual Properties in Higher Educational Institutions and the data lead expose competent universities which act as role model to build-up patent ecosystem in universities, in extension the study provide evidence for industry to capitalise university innovation potentials.
\end{abstract}

Keywords: Higher Education Institution, Indian Universities, Patents, University Patents

\section{Introduction}

Universities had long history of interaction with government, Industry and Society this phenomenon discovered its way to "Third Mission" which meant to serve the society at wider through knowledge as well as infrastructural facilities accommodated at universities; the core theme of the mission was to promote knowledge, transfer the knowledge, exchange and apply such knowledge. It ought to address the requirements of industry for boosting universities contribution

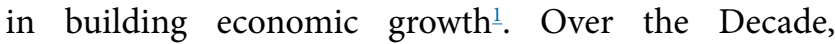
Universities confronted far-reaching impact of financial crises, complex knowledge production and competition across other institution for which universities gripped on "Third Mission" coherently in exuding university valorisation, innovation policies, knowledge investment and technology transfer 2 ?
Universities viewed collaboration with industry was critical for skill development, generation of Innovation and Technology, Kindling Entrepreneurship through start-ups and positioning public funded research in the industry domain. On the flip side, industries resorted to universities for accessing knowledge to encountered transition in technologies, reduced product life cycle and globalisation paved way for intensified competition. The interaction between university and industry regime clearly signalled exchange of benefits ${ }^{4}$.

At individual level faculties are motivated to forge engagement with industry could further their relevance for research, to exploit the knowledge commercially and getting access to research data infrastructure of industry through various channels like joint research, contract research and etc. these instances are undertaken by faculties to gain insights and knowledge rather than commercializing, patenting, licensing and spinoff ${ }^{5}$.

${ }^{*}$ Author for correspondence 
However, the functioning and priority of UniversityIndustry interaction in developing country is different from developed country, the former is shaken by inexperience in maintaining long term collaboration which would ultimately impact commercially exploitable patents, licensing and spin-offs. To strengthen University-Industry collaboration policies in favour of research grants, reward system, Intellectual property and technology transfer office and incubators were established in many developing countries ${ }^{4}$. It is evident that University-Industry interaction still less intense $\mathrm{e}^{6}$, anchoring the tensions of IP management concerns, publication freedoms, misalignment between academic goals and Technology transfer ${ }^{7}$. However, UniversityIndustry collaboration endeavour patents while faculties engaging in the pursuit of indigenous research interests', research on contract, joint research with governmental agencies or industry as partners $\underline{\underline{6}-8}$. R\&D intensive industry seeks patent protection and values those institutes in sponsoring research to establish research partnerships. Since patenting is the preliminary phase in indicating commercial exploitation². Patents are taken as a visible method of technology transfer and often used as an indicator of innovative and R\&D output ${ }^{9}$.

Against this Picture, very little is known about the extent of patents generated in Indian Universities, particularly question rises on how many patents had been sprouted over the years. Thus, we tried to explore the relationship between a university and patenting activities in India, Generally, there are at least two diverse types of university-related patents - patents that are owned by the university, and patents that were invented by researchers who are employed by universities. While the former is usually referred to as university patents, the latter could be referred to as academic patents.

The Key intuition behind a collection of data for university patent is in fact, Government of India boosting ecosystem whereby creating platforms for universityIndustry interactions, generating IP, Innovation culture and establishing new Higher Education Institutions. Keeping Government stimulant for research in mind a curiosity factor arises in understanding what role that Higher Education Institutions has contributed to developing national competitiveness in terms of generating patents. The objective of this paper is to survey the patents granted to Indian universities confining only to Central, State, Deemed and Private universities in India between the periods 1958 to 2017 i.e. 59 years, sourced through INPASS: Indian Patent Advanced Search System Database. The purpose extents in identifying top universities that majored in patent contribution, the area of an invention that weighs more in patents over the years, Rationalisation for disproportionate patents secured by universities falls outside the scope of this paper. In total we witnessed 393 patents granted in the various fields of the invention to 65 universities; a majority of the patents are delivered by Indian Institute of science, Delhi University and by few universities. On contrary to our expectation, the patents count for many universities is less significant or even at the nascent stage.

The paper is organised into six sections, the following section throws light on Indian Context of science policies and section 3 brief histories on the Indian patent regime. Section 4 illustrate the method adopted to gather the base data, furthermore section 5 throws lights on the University patents granted statistics, which intends to detail patents granted to each category of universities and area of patents. Finally, section 6 presents final remarks with a further direction of research.

\section{Indian Context}

After Indian Independence in 1947, Government of India conceived Five-year plan concept to usher economic development is a systematic way. Concern on an expenditure of higher education is absolute, rapidly growing higher education sector suffers setback till now in terms of finance, there were 19 universities at the time of Independence ${ }^{10}$. Expenditure on higher education was gradually hiked from 15 crores in the first five-year plan (1951-56) to Rs. 1,10,700 crores in twelfth five-year plan 2012-2017를 All these spending are reflected in the establishment of 864 universities, 40026 colleges, 11669 standalone institutions and 864 universities which was evidenced in All India Survey on Higher Education, $2016^{12}$.

The primary responsibility of Higher education institutions is to generate, disseminate knowledge and to promote technological innovation and know how. The government of India understood the importance of university-industry collaboration for its role in nation's development, which is reflected in national policy on education of India released by Ministry of Human Resource Development in $1986^{\frac{13}{3}}$. The policy highlighted promoting efficiency and effectiveness at all 
levels encouraging the teachers to provide services to community and industry through the facilities equipped in the institutions; adding to such vision the policy emphasized proactive interaction between industry and institution in research, consultancy and other areas of mutual interest.

Over the years Government of India witnessed four distinguished science policies to foster linkage between University and academia, the main elements of the policies in line with technology transfer are as follows.

Scientific Policy Resolution 1958 $\frac{14}{4}$

- Establish research laboratory and technical academic institutions emphasising on technical Human Resource.

- Create a pool of scientific personnel.

- Technology policy statement $1983^{15}$

- Establish a financial mechanism to invest in pilot plants, prototype developments and enable commercial exploitation of technologies developed at laboratories.

- Create Linkages through Setting up R\&D units in Industry to establish an interface between national laboratories and educational sectors.

- Science and Technology policy $2003^{\frac{16}{6}}$

- Promote basic research by creating, remodifying, strengthening funding structures and Ensure mobility of talented scientists and technologist between academia and industry to encourage and productivity in research

- Create of Technology transfer Offices (TTO) to foster Technology transfer of Know How generated at Universities.

- Special Weight on International Science and Technology cooperation between Developing countries and Indian Academic Institution and Laboratory.

- Science, Technology \& Innovation policy $2013^{17}$

- Enable research community to access advanced research facilities by creating Inter-university centres.

- Modify IPR policy to attract private partnership in Research \& Development and sharing IPR between investor and inventor.

- Launch Technology Business Incubators (TBI and Nurturing science -led entrepreneurship)
- Devise Mechanism to foster University-industry partnership models.

The system of technology transfer from university to industry was majorly reformed since Science and Technology policy 2003. Over decades, only notable Technical institutions' like IIT Bombay, IIT Delhi acted as a cradle for success stories in university technology $1 \underline{18}-\underline{19}$. However, a considerable amount of university-industry collaboration impediments was evidenced by many researchers $\underline{20}-\underline{22}$.

To strength, the collective Research and Development, University-industry interaction and technology transfer various public agencies floated and implemented many schemes. The Selected Public agencies schemes and highlights related to Universities are presented in our research. Department of Science and Technology (DST) announced 'Prime Minister's Fellowship Scheme for Doctoral research' dedicated fellowship programme for individuals to enhance university-industry linkage. The agency had developed a funding mechanism in setting up 'Technology business Incubators' (TBI) in universities to promote research focusing on patent generation, industrial problems, and technology-oriented issues. As of 2013, the Technology Development Board of Science and technology had provided assistance of ' 10 million each to 36 Technology Business Incubators (TBIs) and Science \& Technology Entrepreneur Parks. To garner patents, it has established 'Technology Information, Forecasting Assessment Council (TIFAC), furthermore, TIFAC established 24 Patent Information Centre (PIC) under Patent Facilitation Cell (PFC). These PICs are also creating Intellectual Property Cells in Universities (IPCU) of their respective states. As of 2013, 71 IPCU's have been created in different universities of the states. In addition, they are also liable to provide assistance to the inventors from Govt. organizations, State Universities, Govt. industries for patent searches to find out the potential and assessment of the invention $\underline{23,24}$.

'Ministry of Human Resource Development (MHRD)' to strengthen the University ties with industry might initiate 'Academic Industry Interface Council' as the window where corporate can collaborate with higher education institution in infrastructure creation, Research and scholarships. Furthermore, the ministry appeared to create incubation funds and 100 incubation units after meeting equivalent grants from industry. 


\section{Indian Patent Regime}

Patent law not all new to India, an act related to inventions was enforced in 1856 by British which aimed to protect inventions to induce inventors to disclose the invention and useful manufacturing secret based on the British parliament in 1852 where the privilege of ownership was granted for 14 years. After independence in 1947, it was observed that existing Patents and Designs act 1911 was not enough to address the laid Objectives and thus the government of India shown in interest towards enacting reconstructed patent law owing to substantial changes in political and economic conditions in a country. The new patent act 1970, the first patent law of Independent India was enforced from 20 April; the act allowed patenting of for process inventions in fields like pharmaceutical, agrochemicals, foods products and certain other categories for 16 years and subsequently converted to 20 years in the second amendment. The act remained in force for 28 years and replaced by the Third Patent (Amendment) Act 2005 after two previous amendments in 1999 and 2002 with an act named as the patents (Amendment) Act 2005. The Patent Amendment act 2005 was framed to comply with TRIPS where member countries are subjected to upgrade their patent systems in par with global standards by amending patents for all field of science. However, methods of agriculture, essentially biological processes, plants and animals in whole or any part thereof, cannot be patented, but genes, micro-organisms, etc. with significant human interventions can be patented ${ }^{25}$, In 2016 National IPR Policy was approved by the Indian cabinet to ensure compliance with TRIPS agreement. The Department of Industrial Policy and Promotion has set Intellectual policy for a nation to construct a conducive ecosystem for innovation, IP awareness creation, generation of Intellectual assets, commercialisation. Therefore, one such policy promotes stimulation of Intellectual Properties' by recognising the pool of talents in public research units and ensure commercialisation in academia organised through arrangements common platforms like incubation units, research parks, Cell for IPR Promotion and Management $(\mathrm{CIPAM})^{26}$.

\section{Method}

Patent as a unit of analysis, the investigation resorted to patents granted in India for Indian universities. The patent granted data was retrieved from INPASS: Indian Patent
Advanced Search System which was launched in 2015 by Controller General of Patents Designs and Trademark, a search system where any person can retrieve the granted and pending patent information through Patent E- Register which contain detail such as Applicants Name, Assignee Name, Inventors name, Applicant Address, Field of Patent, Patent application number along with date of patent filing and etc. We attempted to retrieve data for 59 years i.e. 1958 to 2017 as on 28 December 2018, For the purpose of this research 892 Universities name list was found in the list furnished by University Grand Commission in its website as on 20 December 2018 which was categorised to Central Universities (48), State Universities (394), State Private Universities (325) and Deemed to be Universities (125). We excluded institutions of national importance like Indian Institutes of Technologies, National Institute of Technologies and open universities. To ensure data quality, we set university's name as a keyword in "Applicant Name" field so that patent details of the particular university can be displayed; for example, we kept "Hyderabad university" as a keyword for "Applicant Name", the process yielded 5 results and the same process was followed for all the universities. From the output pages, we organised information such as granted patents with filing date, application number, the field of patent and Applicants to whom the patents are assigned. We eliminated duplicate entries to assure data quality, after organising the retrieved information, we ascertained only 65 universities had been granted patents out of 892 . Overall, we found 393 patents have been granted to universities, Furthermore, we listed patents counts for each university according to categories and fields on which it had been accounted along with the percentage of their contribution. The university patent granted data was available and emulated till 2013, Hence we assume the database may suffer in recent update of information and we eliminated 58 patents while apportioning only for field of patents since respective field was not mentioned in E patent register and nowhere to be traced, although it was included in calculating total number of granted patents to universities.

\section{Results}

In Figure 1, the annualised trend of granted patents stand at 393 and made visual as per patent filed date between the period 1958 and 2017, the number of patents filed and 


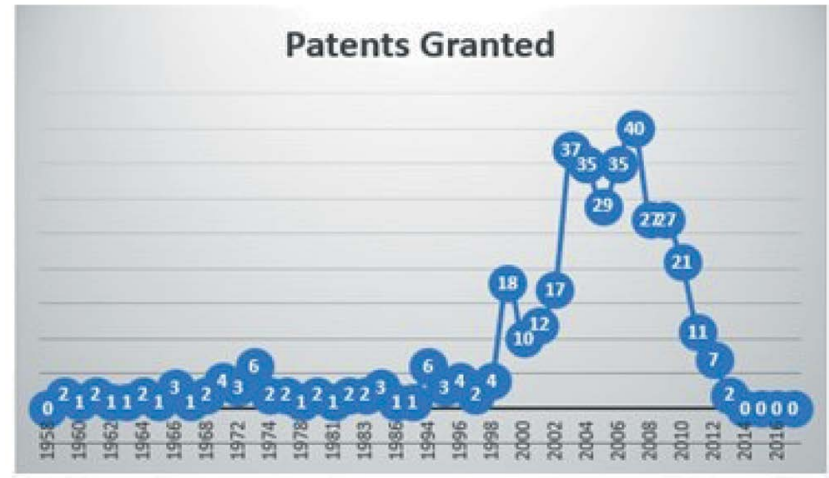

Figure 1. Patent trend for the period between 1958-2017. granted was just 2 in 1959 and increased to twenty times i.e. 40, respectively in 2007 and it dropped 2 in 2014. The patent filing was almost constant from 1957 to 1998. Nevertheless, after 1985 surge in patents filed and granted was observed post TRIPS agreements, united effort by setting befitting policies (e.g. Science and Technology Policy 2003) and amendments in Indian patent act, 1970 which was brought in 2005.

Table 1, the role of university patenting participation was accounted to 393 patents, which has been contributed by $8 \%$ of universities in 59 years. A substantial disparity was found in overall universities participation or the only a handful of universities are active in patenting in their respective categories. The central Universities participation in its category accounted 23\%, which has been relatively higher in proportion as compared to other categories, followed by state universities $10 \%$, Deemed universities 8\% and State Private Universities marked least participation explained in terms of number of granted patents (9) and numbers of universities (10). A number of state Universities participation was more than half of the total number of universities involved in patenting activity, furthermore, it has $31 \%$ of share in total patented granted to universities. However, we observed $8 \%$ of deemed universities has been granted with 213 patents, a significant rate of 54\%, followed by 122 patents contributed by state universities and 49 patents by central universities.

Table 2 lay out the ranking secured by Central universities, it is evident that Delhi University is at the top, tenably against other universities and thus contributed much to the extent of $47 \%$ (23) followed by University of Hyderabad 10\% (5), Banaras Hindu University 10\% (5). Whereas other universities had been granted less than $8 \%$ patents, excluding Delhi University in central university segment, other universities in contributed less in patenting activity.

The patenting activity has not been equal across state Universities, and the same is evident from Table 3. Majority of patents are driven by CSS Haryana Agricultural University which constitute $12 \%$ (15) of the total, followed by GB Pant university $11 \%$ (14), Anna University 8\% (10), North Maharashtra University 7\% (9), Pune University 7\% (8), Jadavpur University 7\% (8), Tamilnadu agricultural University 4\% (5) and universities including Saurashtra University, Sardar Patel University, Punjab agricultural university, North Maharashtra University has been granted modestly each up to $3 \%$ patents, remaining universities collectively accounted to $30 \%(38)$.

Table 1. University participation in patenting activity

\begin{tabular}{|l|c|c|c|c|}
\hline \multicolumn{1}{|c|}{$\begin{array}{c}\text { Categories of } \\
\text { Universities }\end{array}$} & $\begin{array}{c}\text { Number of } \\
\text { Universities }\end{array}$ & $\begin{array}{c}\text { Number of Universities } \\
\text { Involved in Patenting } \\
\text { Activity }\end{array}$ & $\begin{array}{c}\text { Percentage of university involved } \\
\text { in patenting activity (Column IV/ } \\
\text { Column II = Percentage of Patenting } \\
\text { Activity) }\end{array}$ & $\begin{array}{c}\text { Patents Granted to } \\
\text { Universities }\end{array}$ \\
\hline Central University & 48 & 11 & $23 \%$ & $49(12 \%)$ \\
\hline State University & 394 & 40 & $10 \%$ & $122(31 \%)$ \\
\hline $\begin{array}{l}\text { State Private } \\
\text { University } \\
\text { University }\end{array}$ & 325 & 4 & 10 & $9(2 \%)$ \\
\hline Total & 125 & 69 & $-8 \%$ & $213(54 \%)$ \\
\hline Patents Granted & - & 10 & - & - \\
\hline
\end{tabular}


Table 2. Central universities ranking

\begin{tabular}{|l|c|c|}
\hline Central universities & $\begin{array}{c}\text { Patents Granted } \\
\text { (1958- 2017) }\end{array}$ & Percentage \\
\hline Delhi university & 23 & $47 \%$ \\
\hline $\begin{array}{l}\text { University of } \\
\text { Hyderabad }\end{array}$ & 5 & $10 \%$ \\
\hline $\begin{array}{l}\text { Banaras Hindu } \\
\text { university }\end{array}$ & 5 & $10 \%$ \\
\hline $\begin{array}{l}\text { Central university } \\
\text { Punjab }\end{array}$ & 3 & $8 \%$ \\
\hline $\begin{array}{l}\text { University of } \\
\text { Allahabad }\end{array}$ & 3 & $6 \%$ \\
\hline $\begin{array}{l}\text { Jawaharlal Nehru } \\
\text { university }\end{array}$ & 1 & $6 \%$ \\
\hline University of Kerala & 1 & $4 \%$ \\
\hline $\begin{array}{l}\text { North Eastern Hill } \\
\text { University }\end{array}$ & 1 & $2 \%$ \\
\hline $\begin{array}{l}\text { Pondicherry } \\
\text { University }\end{array}$ & $100.00 \%$ \\
\hline Manipur University & 1 & $2 \%$ \\
\hline JamiaMilliaIslamia & 1 & $2 \%$ \\
\hline Total & 1 & \\
\hline
\end{tabular}

Table 3. State universities ranking

\begin{tabular}{|l|c|c|}
\hline \multicolumn{1}{|c|}{ State universities } & $\begin{array}{c}\text { Patents Granted } \\
(\mathbf{1 9 5 8 - 2 0 1 7 )}\end{array}$ & Percentage \\
\hline $\begin{array}{l}\text { ChaudharyCharan } \\
\text { Singh Haryana } \\
\text { Agricultural University }\end{array}$ & 15 & $12 \%$ \\
\hline $\begin{array}{l}\text { G.B. Pant University } \\
\text { of Agriculture \& } \\
\text { Technology }\end{array}$ & 14 & $11 \%$ \\
\hline Anna University & 10 & $8 \%$ \\
\hline $\begin{array}{l}\text { North Maharashtra } \\
\text { University }\end{array}$ & 9 & $7 \%$ \\
\hline Jadavpur University & 8 & $7 \%$ \\
\hline Pune University & 5 & $7 \%$ \\
\hline $\begin{array}{l}\text { Tamil Nadu Agricultural } \\
\text { University }\end{array}$ & 4 & $3 \%$ \\
\hline $\begin{array}{l}\text { Punjab Agricultural } \\
\text { University }\end{array}$ & 3 & $2 \%$ \\
\hline University of Calcutta & 4 & $2 \%$ \\
\hline $\begin{array}{l}\text { Cochin University of } \\
\text { Science and Technology }\end{array}$ & $3 \%$ \\
\hline Sardar Patel University & 3 & \\
\hline
\end{tabular}

\begin{tabular}{|l|c|c|}
\hline Saurashtra University & 3 & $2 \%$ \\
\hline Others & 36 & $30 \%$ \\
\hline Total & 122 & $100 \%$ \\
\hline
\end{tabular}

Table 4. Deemed and private universities ranking

\begin{tabular}{|l|c|c|}
\hline \multicolumn{1}{|c|}{ Deemed Universities } & $\begin{array}{c}\text { Patents } \\
\text { Granted } \\
(1958-2017)\end{array}$ & Percentage \\
\hline Indian Institute of Science & 146 & $69 \%$ \\
\hline $\begin{array}{l}\text { Institute of Chemical } \\
\text { Technology }\end{array}$ & 13 & $6 \%$ \\
\hline $\begin{array}{l}\text { Tata Institute of } \\
\text { Fundamental Research }\end{array}$ & 13 & $6 \%$ \\
\hline $\begin{array}{l}\text { Jawaharlal Nehru Centre for } \\
\text { Advanced Scientific Research }\end{array}$ & 11 & $5 \%$ \\
\hline Birla Institute of Technology & 11 & $5 \%$ \\
\hline JamiaHumdard university & 10 & $5 \%$ \\
\hline $\begin{array}{l}\text { National Dairy Research } \\
\text { Institute }\end{array}$ & 3 & $1 \%$ \\
\hline $\begin{array}{l}\text { Birla Institute of Technology } \\
\text { and Science }\end{array}$ & 3 & $1 \%$ \\
\hline $\begin{array}{l}\text { Amrita } \\
\text { VishwaVidyapeetham }\end{array}$ & 2 & $1 \%$ \\
\hline $\begin{array}{l}\text { DR. M.G.R. Educational and } \\
\text { Research Institute University }\end{array}$ & 1 & $1 \%$ \\
\hline Total & 213 & $100 \%$ \\
\hline Private Universities & 1 & $67 \%$ \\
\hline Amity University & $11 \%$ \\
\hline $\begin{array}{l}\text { Lovely Professional } \\
\text { University }\end{array}$ & $11 \%$ \\
\hline $\begin{array}{l}\text { Charotar University of } \\
\text { Science \& Technology }\end{array}$ & $\begin{array}{l}\text { Jaypee University of } \\
\text { Information Technology }\end{array}$ & $100 \%$ \\
\hline Total & 1 & \\
\hline
\end{tabular}

Table 4, reports collection of patents assigned to deemed and state private universities. Further quantification reveals Indian Institute of Science hold 69\% (146) patents and Amity University contributed 67\% (9) patents in their respective category. In the context of the deemed university, some universities like Institute of chemical technology, TATA Institute of Fundamental Research, Birla Institute of Technology, Jamia Humdard and Jawaharlal Nehru Centre for Advanced Research have secured more than 10 patents each however other universities in the slot certainly not contributed in 
weighing up the patent number. Private university list suggests that apart from Amity University's patent augmentation other universities' part was minor.

Table 5, List of top 10 universities till 2017 accounts to two third (265) of the patent granted to universities. Indian Institute of science is the dominant patents producer, IISc carries one third (146) of patents granted, which is relatively a significant as compared to any other university whose patent counts are unsubstantial. Delhi University ranked 2nd with 23 patents followed by Chaudhary Charan Singh Haryana Agricultural University with 15 patents, G.B.Pant University of Agriculture, Technology at 3rd with 14 patents, Institute of Chemical Technology (13), Tata Institute of Fundamental Research (12), Birla Institute of Technology (11), Jawaharlal Nehru Centre

Table 5. Top 10 universities ranking

\begin{tabular}{|l|c|}
\hline \multicolumn{1}{|c|}{ Top 10 Universities } & $\begin{array}{c}\text { Patent Granted } \\
(\mathbf{1 9 5 8 - 2 0 1 7 )}\end{array}$ \\
\hline Indian Institute of Science & 146 \\
\hline Delhi University & 23 \\
\hline $\begin{array}{l}\text { ChaudharyCharan Singh Haryana } \\
\text { Agricultural University }\end{array}$ & 15 \\
\hline $\begin{array}{l}\text { G.B.Pant University of Agriculture and } \\
\text { Technology }\end{array}$ & 13 \\
\hline Institute of Chemical Technology & 13 \\
\hline Tata Institute of Fundamental Research & 11 \\
\hline Birla Institute of Technology & 11 \\
\hline $\begin{array}{l}\text { Jawaharlal Nehru Centre for Advanced } \\
\text { Scientific Research }\end{array}$ & 10 \\
\hline JamiaHamdard University & 10 \\
\hline Anna University & 13 \\
\hline
\end{tabular}

for Advanced scientific research (11), Jamia Hamdard University and Anna university stand at 10th position with 10 patents.

Table 6, represents the propensity of university patenting in varying fields, high number of patents granted (77) was in chemical that accounted for $23 \%$, the same have been depicted by Table 6 and outline the patents granted in the biotechnology 15\% (50), Mechanical engineering 11\% (36), Pharmaceuticals 10\% (33), Electrical 8\% (27),
Bio Chemistry 7\% (25), Micro Biology 6\% (20), General engineering 5\% (17). However, Metallurgy, polymer

Table 6. Area of patents granted

\begin{tabular}{|l|c|c|}
\hline \multicolumn{1}{|c|}{ Area } & $\begin{array}{c}\text { Patents Granted } \\
(\mathbf{1 9 5 8 - 2 0 1 7 )}\end{array}$ & Percentage \\
\hline Chemical & 77 & $23 \%$ \\
\hline Biotechnology & 50 & $15 \%$ \\
\hline $\begin{array}{l}\text { Mechanical } \\
\text { Engineering }\end{array}$ & 36 & $11 \%$ \\
\hline Pharmaceuticals & 33 & $10 \%$ \\
\hline Electrical & 27 & $8 \%$ \\
\hline Bio-Chemistry & 25 & $7 \%$ \\
\hline Micro Biology & 20 & $6 \%$ \\
\hline General Engineering & 17 & $5 \%$ \\
\hline Metallurgy & 11 & $3 \%$ \\
\hline Polymer Technology & 9 & $3 \%$ \\
\hline Food & 8 & $2 \%$ \\
\hline Physics & 7 & $2 \%$ \\
\hline Electronics & 7 & $2 \%$ \\
\hline Communication & 4 & $1 \%$ \\
\hline Computer Science & 4 & $1 \%$ \\
\hline Agrochemicals & 3 & $0 \%$ \\
\hline Textile & 1 & \\
\hline
\end{tabular}

technology, Food, Physics, electronics, communication, computer science, agrochemical and textile are those areas where the patents granted less than $5 \%$.

\section{Final Remarks}

Initiatives were taken by the government to align with Trade-related aspects of Intellectual Property Rights (TRIPS) and stimulants to create research, innovation and patenting culture in academia created through science policies and other agencies laid strategy to achieve patenting activity. Although many Indian universities are yet to make a significant contribution in terms patent contribution, the universities are seemed to be on course in increasing patent contribution. Patents trend indicates the intensity of patenting activity which represents the innovation paradigm of universities; there has been a growth in patenting after TRIPS and its reflection in 2005 through amendment of patent act 1970. 
Most of the patents are generated by Deemed to be Universities $54 \%$ patents were not equally distributed across universities and fields. A university such as Indian Institute of science generated significant patents as compared to universities in other categories over the past 59 years. Notable contributions were also made by Delhi University, Chaudhary Charan Singh Haryana Agricultural University, G.B. Pant University of Agriculture and Technology and Institute of chemical technology, although generated enough patents their respective lot, each has relatively low share in the total number of patents granted. Among University categories, Participation of central universities tends to be higher. Certain fields of technology have registered higher progress than others, in particular fields like the chemical. Biotechnology, mechanical engineering, pharmaceuticals.

We are able to slice the reliable information on patents granted to Indian universities patent generation and performance on patent production across technological wide based on data retrieved and assembled from INPASS, such information may be limited by perceived noises. we conclude that there has been development in patent growth after 1985 through measures of the government of India through Amendments in the patent act, Scientific policies and infrastructure build around to embrace research and intellectual Properties however decline in activity is also observed in recent years, overall university Patenting regime is at the nascent stage.

The extension of the study would be tracing the patents generated by institutions of national importance and reasons for the disproportionate filing of patents across universities, the future should cover university invented patent dimension. The work should address the importance of university invented patents coupled with the development of a novel methodology to narrow down to university invented patents. Thus, a line of work shall facilitate the debate on universities contribution in enhancing national competitions through creating patents.

\section{References}

1. Etzkowitz $H$. The norms of entrepreneurial science: cognitive effects of the new university-industry linkages. Research policy. 1998; 27(8): 823-833. https://doi. org/10.1016/S0048-7333(98)00093-6.

2. Perkmann M, Tartari V, McKelvey M, Autio E, Brostrom A, D'Este, PerkmannSobrero M. Academic engagement and commercialisation: A review of the literature on universityindustry relations. Research Policy. 2013; 42, 423-442. https://doi.org/10.1016/j.respol.2012.09.007.

3. Zomer A, Benneworth P. The Rise of the University's Third Mission. Reform of Higher Education in Europe. 2011; 81-101. https://doi.org/10.1007/978-94-6091-555-0_6.

4. Guimon J. Promoting University-Industry Collaboration in Developing Countries. Tech. rep. 2013.

5. D'Este P, Perkmann M. Why do academics engage with industry? The entrepreneurial university and individual motivations. Journal of Technology Transfer. 2011; 36: 316-339. https://doi.org/10.1007/s10961-010-9153-z

6. Joseph KJ, Abraham V. University-Industry Interactions and Innovation in India: Patterns, Determinants, and Effects in Selected Industries. Seoul Journal of Economics. 2009; 22: 467-498.

7. Kneller R, Mongeon M, Cope J, Garner C, Ternouth P. Industry-university collaborations in Canada, Japan, the UK and USA - With emphasis on publication freedom and managing the intellectual property lock-up problem. PLoS ONE. 2014; 9: 1-19. https://doi.org/10.1371/journal. pone.0090302.

8. Universities and their exploitation of intellectual property [internet]. https://www.researchgate.net/ publication/27828679_Universities_and_Their_ Exploitation_of_Intellectual_Property. Date accessed: 06/01/1996.

9. Henderson R, Jaffe AB, Trajtenberg M. Universities as a source of commercial technology: A detailed analysis of university patenting, 1965-1988. Review of Economics and Statistics. 1998; 80: 119-127. https://doi.org/10.1162/003465398557221

10. Higher Education Expenditure in India. Imperial Journal of Interdisciplinary Research [internet]. https://www. onlinejournal.in/IJIRV2I5/256.pdf. Date accessed: 2016.

11. Planning Commission and others. Twelfth Five Year Plan (2012-17) Social Sectors Volume III. Government of India, New Delhi. 2013; 1-292.

12. Ministry of Human Resource Development. Department of Higher Education [internet]. http://aishe.nic.in/aishe/ viewDocument.action?documentId=239. Date accessed: 2017.

13. Ministry of Human Resource Development. Department of Education [internet]. http://www.ncert.nic.in/oth_anoun/ Policy_1986_eng.pdf. Date accessed: 1986.

14. Ministry of Science and Technology. Scientific Policy Resolution 1958 [internet]. Retrieved from http://www. nstmis-dst.org/SPResolution.aspx. Date accessed: 1958 .

15. Ministry of Science and Technology. Technology Policy Statement [internet]. http://www.nstmis-dst.org/ TPStatement.aspx. Date accessed: 1983. 
16. Ministry of Science and Technology. Science and Technology Policy [internet]. https://journals.sagepub. com/doi/pdf/10.1177/097172180300800105. Date accessed: 2003.

17. Department of Science and Technology. 2012 annual report of Department of science and Technology [internet]. Retrieved from http://dst.gov.in/sites/default/files/annualreport-2012-13_0.pdf. Date accessed: 2013.

18. Arumugam V, Jain K. Technology transfer from higher technical institutions to the industry in India - A case study of IIT Bombay. Journal of Intellectual Property Rights. 2012; 17:141-151.

19. Bhattacharya P. Technology transfer from a technical university: a case study of IIT Delhi. Journal of Intellectual Property Rights. 2005; 10: 413-416.

20. Gandhi MM. Industry-academia collaboration in India: Recent initiatives, issues, challenges, opportunities and strategies. The Business Management Review. 2014; 5: 11-12.

21. Ansari MM, Sharma TC. Industry and Universities in India: Is the Collaborative Effort Succeeding? Industry and Higher Education. 1991; 5: 143-154. https://doi. org/10.1177/095042229100500304.

22. Kumar P, Gupta R. The Roadmap for Enhancing University-Industry Research Collaboration in India. Indian Journal of Public Administration. 2017; 63: 196-227. https://doi. org/10.1177/0019556117699735.

23. Ministry of Science and Technology. Science, Technology and Innovation Policy [internet]. http://www.dst.gov.in/ sites/default/files/STI\%20Policy\%202013-English.pdf. Date accessed: 2013.

24. University Grand Commission. Total No. of Universities in the Country as on [internet]. https://www.ugc.ac.in/ oldpdf/Consolidated_CENTRAL_UNIVERSITIES_List. pdf. Date accessed: 2018.

25. Controller General of Patents, Designs and Trade. History of Indian Patents System [internet]. http://www.ipindia.nic. in/history-of-indian-patent-system.htm. Date accessed: 05/12/2018.

26. Ministry of Department of Industrial Policy \& Promotion. National Intellectual Policy [internet]. https:/dipp.gov.in/ sites/default/files/National_IPR_Policy_English.pdf. Date accessed: 2016. 